\title{
Students' Perception on the Problem in Translating Humor Text
}

\author{
Raihana Tuzzikriah $^{1^{*}}$ and Havid Ardi $^{2}$ \\ ${ }^{1}$ English Department, FBS Universitas Negeri Padang, Padang, Sumatra Barat 25131, Indonesia \\ ${ }^{2}$ English Department, FBS Universitas Negeri Padang, Padang, Sumatra Barat 25131, Indonesia \\ *Corresponding author. Email: raihana267@gmail.com
}

\begin{abstract}
Humor text is one of the texts that are translated from English into Indonesian context. However, translating humor is not easy as it is influence by various factors. This study aims to find out the students' perception on the problem in translating humor text. It is a descriptive research that describes the perception of students' problems in translating humor text. Data were collected through questionnaires distribution. In analyzing the data, the researchers calculated the perception by using Likert scale. The result of this study showed that the students had perception related to the translation problems in translating humor text. There are several students' perception of the problems in translating humor text such as experience in translating humor text, knowing translation risk, the tools in translating text, the time needed to translate, the way of translating text, the level of difficulty in translating text, and the source of difficulty in translating text.
\end{abstract}

\section{Keywords: Humor Text, Perception, Translation, Translation Problem, Translation Difficulty}

\section{INTRODUCTION}

Entertaining is the goal of creating humor, as stated by Vandaele that humor is what causes people amusement, mirth, a spontaneous smile and laughter [1]. In fact, experts classify several types of humor, such as Attardo and Raskin divided humor into verbal and non-verbal [2], [3]. In verbal humor Dynel stated, there are two types of humor are namely canned jokes and conversational humor [4]. To be more concise, researchers focused on conversational humor which studied in this study, because conversational humor is humor in everyday life that is often used when communicating for entertaining purposes. And there are some conversational humors are of lexemes and phrasemes, witticism, retorts, teasing, banter, putdowns, self-denigrating, and anecdote.

Moreover, humor is a different challenge in itself for translators who usually translate important things and not entertaining, such as business letters, academic essays, political agreements between countries, and others. Additionally, some previous studies have shown that the translation study has discussed some humor translations, such as the research of humor translation in sitcoms [5], humor translation in books [6], humor translation in films [7], [8], and humor translation in comics [9]. Some in this study described translation techniques, types of humor, translation problems in translating humor.

The problem of translating humor has been studied by several experts, such as one of the problems of translating humor is culture. The cultural differences between the source language and the target language in the translation of humor make the context of humor that is owned by the source language very different from the target language [10]. Apart from culture, humor has several types of humor, the translator must have knowledge and experience in translating different types of humor because they have an impact on the translation result [11], [12]. And, some of the problems with translating humor are in terms of language such as semantic, pragmatic, and others [2]. In addition, in translating humorous texts, students need to have a sense of humor because translating humor is to entertain readers of the target language. Therefore, it is difficult to translate humor because each individual has a different sense of humor [13].

In this study, researchers focused on students' perceptions of the problem of humor translation. Meanwhile, some previous studies have discussed students' perceptions of translation [14]-[16]. In these previous studies had explained about students' perception of machine translation. Unfortunately, there were students' perception on problem in translating text.

According to Malim, perception is a dynamic process that involves determining the best possible interpretation of data received through the senses [17]. It is a process of testing hypotheses rather than a passive reflection of sensations received. Meanwhile, according to Slameto, perception is a process that involves the entry of messages or information into the human brain [18] Through perception, humans are constantly in contact with their environment. It can be concluded that one's habits or experiences in translating texts shape one's knowledges and needs in translating texts that are different from other individuals. 
To a translator's knowledge, a translator needs experience in translating several types of humor. This is also clarified by Raskin said that the core of the experience of humor is the perception that something is "funny" [10]. Experience in translating texts of different types of humor is needed to produce good translation results and have a sense of humor appropriate to the target language. Besides, the translator needs to know the risk of translation in translating humorous texts. Because the risk of translation is a risk in translating a text for a translator, this risk can exist around aspects of life because the scope of the science of translation includes human life [19].

To a translator's way in translating text, there are three discussed, they are; First, the tools in translating text. Translation tools needed by translators to make it easier for them to translate text. In this research, the researcher wanted to know what translation tools students usually use in translating text. Second, the researchers wanted to analyze what type of humor they thought took the longest to translate. When someone does something and it takes a long time, it identifies the difficulty of the translation text [20]. Third, the translation approach is used by translators before translating a text. Meanwhile, this approach is a way for the translator to translate text from the source language to the target language [21]. Ardi had categorized several translator approaches, namely the top-down approach is a way for the translator to translate the text by reading over and over and understanding the source text to be translated and secondly the bottom-up approach is the way the translator translates the source text directly word for word, sentence by sentence and so on without analyzing the previous source text [22].

However, translation problems cannot be separated from the difficulties faced by students. In this humor translation difficulty, the researcher classified students' perceptions of the level and source of the difficulty in translating humor. To determine the level of humor translation, the researcher took several types of humor to analyze which type of humor is the most difficult to translate, the researcher takes Dynel's conversational humor types. And, to get solutions to translation problems, translators need to know the source of the difficulty in translating certain texts. As said by Ardi, there are several sources of translator difficulties in translating the text, such as; meaning of word, meaning of phrase, meaning of sentence, meaning of the whole sentence, collocation, idiom, situational and contextual meaning, cultural term [22].

In conclusion, to find out students' perception on problem in translating humor text, researchers would analyze, they are; First, students' knowledge such as experience in translating humor text, knowing translation risks. Second, students' needs to translate humor such as the tools in translating text, the time needed to translate, the way of translating text. And last, students' difficulty in translating humor text such as, the level of difficulty in translating text, and the source of difficulty in translating text.

\section{METHODS}

The researchers used descriptive research. Mills \& Gay said that descriptive research is describe the way things are; involves collecting numerical data to test hypotheses or answer questions about the current subject of study [23]. This study was focus on students' perception on problem of humor translation. The sample of this study was students who was learning translation study in department of English Education at University Negeri Padang. The researchers used close-ended questionnaire as the instruments of this study to collect the data. To analyzed the students' perception, researchers used Likert scale and categorized the students' problems of humor translation.

\section{RESULT AND DISCUSSION}

In this research, researchers used some indicators to determine the students' perception in translating humor text, they are experience in translating humor text, knowing translation risk, the tools in translating text, the time needed to translate, the way of translating text, the level of difficulty in translating text, and the source of difficulty in translating text.

\subsection{Experience in translating humor text}

The experiences students have an influence on their perceptions in responding to something. This also happens in the translation of humor text. In this experience, researchers associated with several types of humor such as lexemes and phrasemes, witticism, retorts, teasing, banter, putdowns, self-denigrating, and anecdotes. Researchers wanted to see students' experiences with what types of humor they know or what types of humor they have translated. This can be seen from their opinion on how much it is necessary to translate certain types of humor.

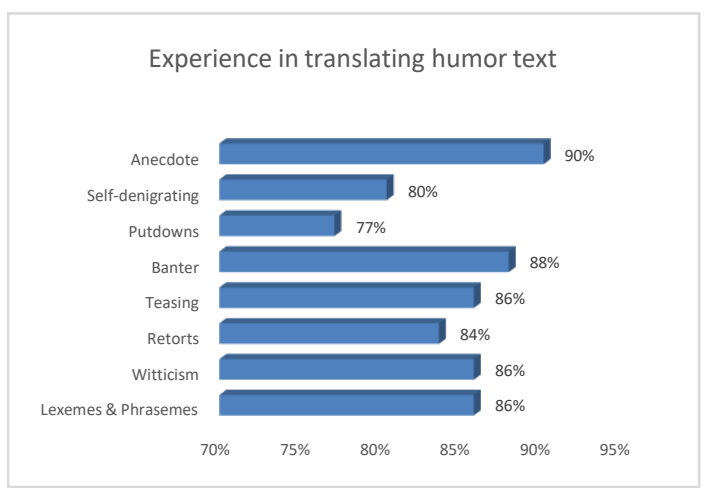

Figure 1. Experience in translating humor text

In the data that has collected, there are some students agree on in the need to translate certain types of 
humor such as (table 3.1); lexemes and phrasemes with a total questionnaire answer of percentage $86 \%$, witticism with a total answer of percentage $86 \%$, retorts with a total questionnaire answer of percentage $84 \%$, teasing with a total questionnaire answer of percentage $86 \%$, banter with a total questionnaire answer of percentage $88 \%$, putdowns with a total questionnaire answer of percentage $77 \%$, selfdenigrating with a total questionnaire answer of percentage $80 \%$ and anecdote with a total questionnaire answer of percentage $90 \%$.

In the data that has been collected, most students agree that they need experience in translating anecdotes. Anecdote has long been studied at the high school level [24], [25]. In fact, in the theory of humor, various types of humor need to be used as experiences for students in translating humor texts. Their understanding and knowing in translating texts of various types of humor are needed to get good translation results.

In this conclusion, the students' perceptions of the need to translate certain types of humor texts have problems. Students will face confusion and misunderstanding of the context of humor itself. Therefore, understanding and knowing in translating various types of humor texts are needed to be able to translate humor texts accurately, be accepted, and understood by the target language.

\subsection{Knowing translation risk}

A translator must know what are the risks that occur when he/she translates text from the source language to the target language. In human life, there are various aspects that a professional translator needs to know. As a prospective professional translator, students are required to know what are the risks in translating a text.

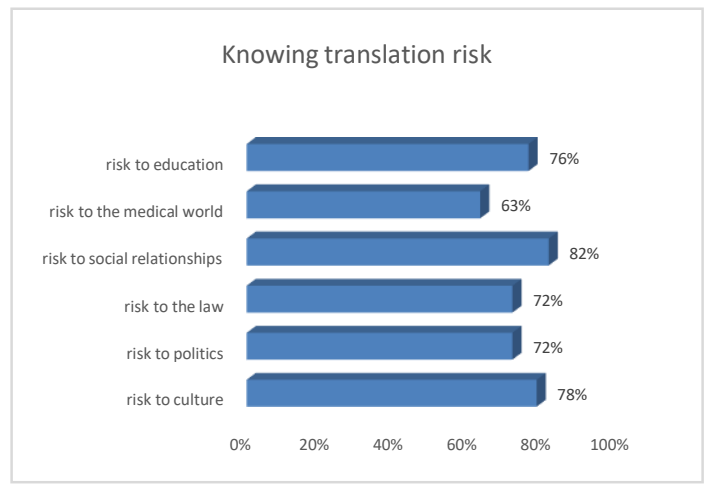

Figure 2. Knowing translation risk

In the data, there are several translation risks which according to the students need to be known in translating humor texts, namely (table 3.2); the risk of translation to culture with a total of $78 \%$, the risk of translation to politics with a total of $72 \%$, the risk of translation to law with a total of $72 \%$, the risk of translation to social relations with a total of $82 \%$, the risk translation in the medical world with a total of $63 \%$, and the risk of translation in education with a total of $76 \%$.

From the data above, it can be concluded that the student's perception of the translation of humor has the highest risk of translation in social relations. In translating humor texts, students need to consider the risk of translation in public relations so that there are no misunderstandings or parties who are offended by the translation of humor from the source language to the target language. Moreover, the problem of translation in translating humor texts is to consider understanding the risks of translation. For this reason, students are needed to understand the social relations between the two different languages and cultures. Understanding and knowing of social relations in the source language and target language will make the translator understand how to translate humor text that has a different sense of humor in the source language or target language.

\subsection{The tools in translating text}

A translation tool is a tool that helps translators in translating text from the source language to the target language. In this study, researchers took several translation tools commonly used by students in translating text in the form of dictionaries and translation applications such as Google Translate, Indonesian English dictionary, Indonesian English dictionary, oxford dictionary, alfalink, and others [26]. The tools that are usually used by students in translating text can become perceptions for students.

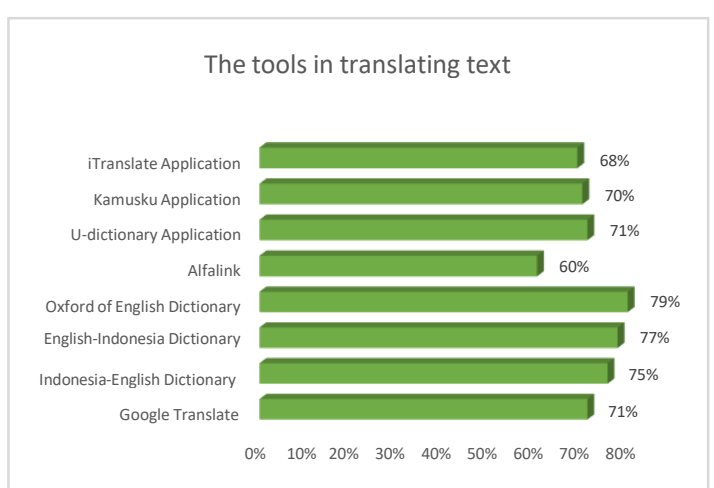

Figure 3. The tools in translating text

The data that has collected (table 3.3), there are Google Translate with a total of percentage $71 \%$, Indonesian-English Dictionary with a total of percentage 75\%, English-Indonesian Dictionary with a total of percentage $77 \%$, Oxford of English Dictionary with a total of percentage $79 \%$, Alfalink with a total of percentage $60 \%$, U-dictionary Application with a total of percentage $71 \%$, Kamusku Application with a total of percentage $70 \%$, and iTranslate Application with a total of percentage $68 \%$.

Based on the data above, the Oxford dictionary is the most approved by students. In this case, the oxford dictionary is only based on word-for-word in the sentence. 
This has an impact on the context in the translation because word-for-word understanding cannot fit the entire context in the sentence. And also, the Oxford dictionary only defines the definition in English words which are foreign languages for students. Besides, in translating humor texts, students must fully understand the text of the source language and understand funny contexts or sense of humor in the target language. So, there is a problem with the translation of humor from the students' perceptions of the translation tool. For that students need to use a variety of translation tools more than once and also seek information from the source language or target language in translating humor texts.

\subsection{The time needed to translate}

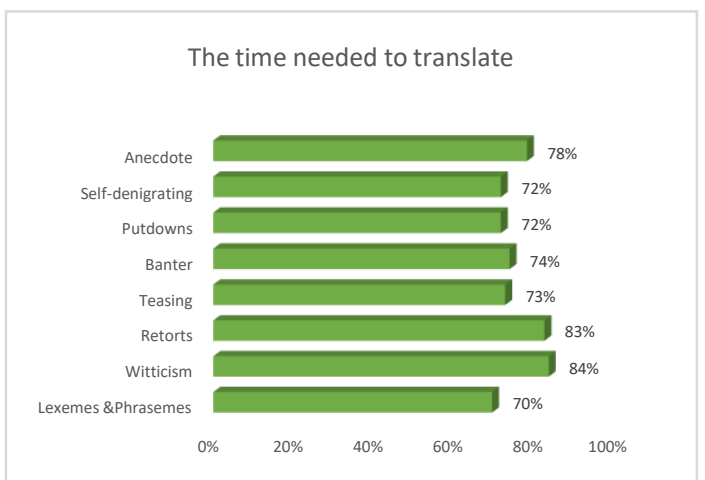

Figure 4. The time needed to translate

Translating humor text over a long time can indicate the difficulties and problems faced by the translator because the translator takes a long time to translate the text from the source language to the target language. Besides, the data on the results of students' perceptions on several types of humor that have collected, they are (table 3.4); lexemes and phrasemes with a total of percentage $70 \%$, witticism with a total of percentage $84 \%$, retorts with a total of percentage $83 \%$, teasing with a total of percentage $73 \%$, banter with a total of percentage $74 \%$, putdowns with a total of percentage $72 \%$, self-denigrating with a total of percentage $72 \%$, and anecdote with a total of percentage $78 \%$.

In conclusion, the data that most students agree on is the most common problem faced by students in translating humor texts is translating witticism of type humor. This type has an ambiguous meaning and is not easy for students to understand. This ambiguous word consideration can be resolved by understanding the entire context in the humor translation of the text from the source language. Then, understand a sense of humor that fits in the target language, to make the humor translation.

\subsection{The way of translating text}

The approach of a translator in translating a text from the source language to the target language is the translator's way of doing his job. In this study, researchers looked for students' perceptions of the way they translated a translated text. Meanwhile, some of the data that has been collected (table 3.5); reading and understanding the humor text of the source language first before translating it has a total of percentage $91 \%$, instantly translate the humor text of the source language while reading and understanding has a total of percentage $73 \%$, re-check the translation of the translated humor text has a total of percentage $91 \%$, look for the ambiguous meaning of a word from the source or target language has a total of percentage $90 \%$ and very interested and enthusiastic when translating humor texts has a total of percentage $88 \%$.

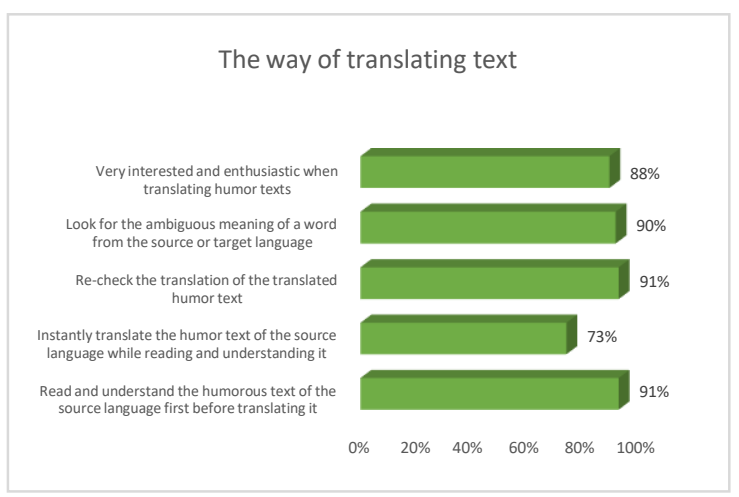

Figure 5. The way of translating text

From the data on students' perceptions of their way of translating humor texts, it can be concluded that students realize the need to read and understand the humor text of the source language when translating it. And also, students think that checking the results of the translation they have done is something they agree with. This is because the humor context and sense of humor of the source language and the target language are very different.

\subsection{The level of difficulty in translating text}

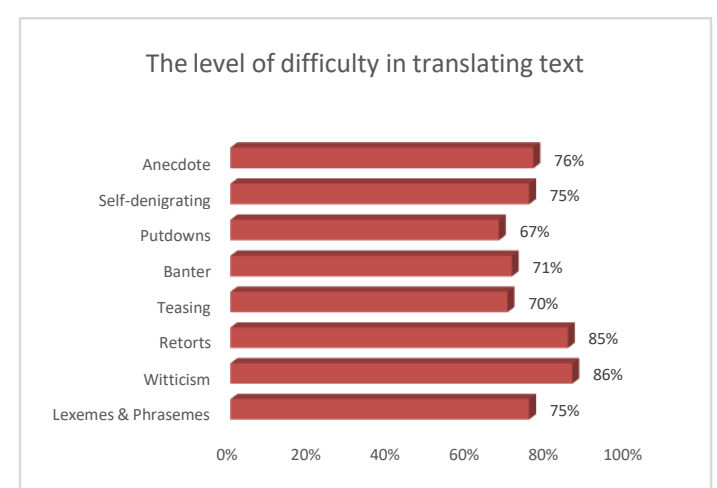

Figure 6. The level of difficulty in translating text

Students' perceptions of the level of difficulty in translating humor texts are needed to find out how the problems of translating humor are. The difficulty in translating humor affects the results of the humor translation that students do. At this level of difficulty, the researcher relates it to several types of humor that have been discussed above. And data from students' perceptions 
on the level of difficulty translating the types of humor are; lexemes and phrasemes with a total percentage of $75 \%$, witticism with a total percentage of $86 \%$, retorts with a total of percentage $85 \%$, teasing with a total of percentage $70 \%$, most with a total of percentage $71 \%$, putdowns with a total of percentage $67 \%$, self-denigrating with a total of a percentage $75 \%$, and anecdote with a total of percentage $76 \%$ (table 3.6).

As previously discussed, the type of humor that takes a long time to translate into a humor text is witticism. And this also affects students' perceptions of the level of difficulty in translating certain types of text humor. Moreover, this is evidenced in the most data on the difficulty level of translation of humor is witticism as well. The ambiguous words make students try hard to understand a funny context. Finally, it can be concluded that witticism is a type of humor that is a problem in translating humor texts. Therefore, students need to read and understand the meaning of the source text and have the same sense of humor as the target language.

\subsection{The source of difficulty in translating text}

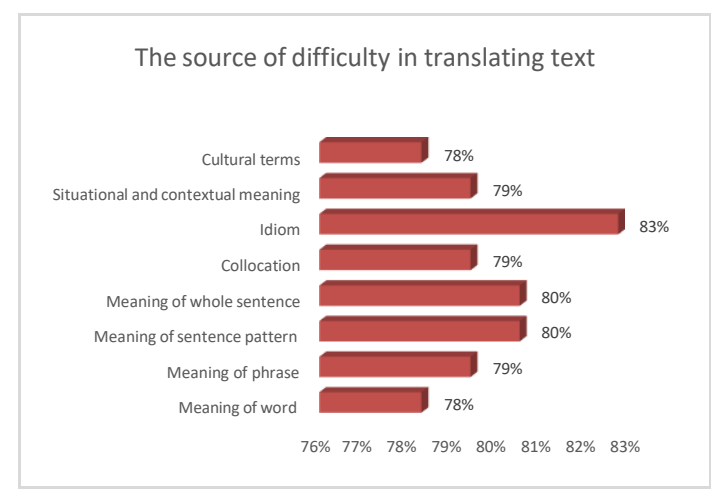

Figure 7. The source of difficulty in translating text

The source of difficulty in translating humor texts is a translation problem that needs to be addressed. Above, we discussed what types of humor have a high level of difficulty. A translator should have the ability to overcome any difficulties he faces in translating texts, especially humor texts. As a professional translator candidate, students need to know what are the sources of difficulty in translating certain texts. In translating humor texts, students have several perceptions of the source of what difficulties they faced, and this has been stated in the following data (table 3.7);

Meaning of word has a total of percentage $78 \%$, Meaning of phrase has a total of percentage 79\%, Meaning of sentence pattern has a total of percentage $80 \%$, Meaning of the whole sentence has a total of percentage $80 \%$, Collocation has a total of percentage $79 \%$, Idiom has a total of percentage $83 \%$, Situational and contextual meaning has a total of percentage $79 \%$, Cultural term has a total of percentage $78 \%$.

From the data above, it can be concluded that students' perceptions of the source of difficulties and problems in translating humorous texts are the highest in idioms. Idioms are words that have different meanings from each word in the idiom. Students need to know other linguistic knowledge such as semantics in source languages and target languages.

\section{CONCLUSION}

In conclusion, the results of students 'perceptions of humor translation, there are several translation problems in translating humorous texts. First, students' perceptions in translating humor only need experience in translating anecdotal-type texts. Second, the risk of social relations in translating humorous texts is a consideration for students because the humor in the translated text can offend other parties. Third, the translation tool that they think is most needed in translating humorous texts is the Oxford of English Dictionary. Fourth, according to them, translating the type of humor witticism takes time in translating the humorous text. Fifth, how they translate the humorous text by reading and understanding it before translating the humorous text and then reviewing the results of their translation. Sixth, the type of humor witticism is the type of humor that is most difficult to translate. Finally, according to them, idioms are a source of translation in translating humorous texts.

Translating humorous texts is not easy, translators need experience and knowledge of humor from different languages and cultures. The translator's sense of humor also determines whether the translation of the source text can convey a funny impression. To overcome ambiguous words in the source text, the translator needs information from the context of the humorous text to be translated. Translators also need translation tools that are suitable for translating humorous texts, because word-for-word translation is not a good solution for translating humorous texts.

\section{REFERENCES}

[1] J. Vandaele, "Humor in translation," Handb. Transl. Stud., vol. 1, pp. 147-152, 2010.

[2] S. Attardo, Humorous texts: A semantic and pragmatic analysis. De Gruyter Mouton, 2001.

[3] V. Raskin, "Semantic mechanisms of humor," in Annual Meeting of the Berkeley Linguistics Society, 1979, vol. 5, pp. 325-335.

[4] M. Dynel, "Beyond a joke: Types of conversational humour," Lang. Linguist. Compass, vol. 3, no. 5, pp. 1284-1299, 2009.

[5] L. Istiqomah, "Students' Translating Humor of Mind Your Language British Comedy in The Indonesian Subtitle," Pustabiblia J. Libr. Inf. Sci., vol. 1, no. 2, p. 185, 2017, doi: 10.18326/pustabiblia.v1i2.185208.

[6] S. A. Aldawood, "Understanding the Strategies Used to Translate Colloquial Egyptian Humour: A Study of Khaled Al Khamissi's Taxi (2006)," Arab World 
English J. Transl. Lit. Stud., vol. 3, no. 3, pp. 188197, 2019, doi: 10.24093/awejtls/vol3no3.15.

[7] P. N. T. R. W. Treetrapetch, "An Analysis of Verbal Humor and Translation Techniques used in The American Comedy Film ' TED' การศ กษากลว ธ การแปลม ขตลกจากภาษาอ งกฤษเป นภาษาไทยในภาพยนตร อเมร ก น เร க8 อง “ เท ด หม ไม ค แอ บแสบได อ ก," vol. 10 , no. 4, 2017.

[8] I. Yuliasri and P. Allen, "Humour loss in the Indonesian translation of Harry Potter and the Sorcerer's Stone," Indones. J. Appl. Linguist., vol. 9, no. 1, pp. 119-127, 2019, doi: 10.17509/ijal.v9i1.14185.

[9] I. Yuliasri, "Translators' censorship in EnglishIndonesian translation of Donald Duck comics," Indones. J. Appl. Linguist., vol. 7, no. 1, pp. 105-116, 2017, doi: 10.17509/ijal.v7i1.6863.

[10] V. Raskin, The primer of humor research, vol. 8. Walter de Gruyter, 2008.

[11] B. Martic, "Humor in Translation," 2020.

[12] F. R. B. Kembaren, "The Challenges And Solutions of Translating Puns and Jokes from English To Indonesian," VISION, vol. 16, no. 2, 2020.

[13] R. Martin, "Sense of humor.," 2003.

[14] R. Siregar, "Exploring the Undergraduate Students Perception on Translation--A Preliminary Step to Teach Translation in EFL Classes.," English Lang. Teach., vol. 11, no. 9, pp. 90-101, 2018.

[15] S. Marito and E. Ashari, "EFL Students 'Perception About Machine Translation," vol. 6, no. 2, pp. 256269, 2017.

[16] S. Sujarwo, "Students' Perceptions of Using Machine Translation Tools In the EFL Classroom," Al-Lisan J. Bhs., vol. 5, no. 2, pp. 230-241, 2020.

[17] T. Malim, Cognitive processes: attention, perception, memory, thinking and language. Macmillan International Higher Education, 1994.

[18] S. Alfabeta, "Belajar dan Faktor-faktor yang Mempengaruhinya," Jakarta. PT. Rineka Cipta, 2003.

[19] A. Pym, "Text and risk in translation," Choice Differ. Transl. specifics Transf., pp. 27-42, 2004.

[20] N. Schwarz, L.-R. Stiegelbauer, And D.-B. Husar, "Translation Problems And Difficulties In Applied Translation Processes.," Stud. Ştiintă şi Cult., vol. 12, no. 3, 2016.

[21] M. R. Nababan, "Strategi penilaian kualitas terjemahan," J. Linguist. Bhs., vol. 2, no. 1, pp. 5465, 2004.

[22] H. Ardi, "Pengantar penerjemahan (Introduction to translation)," 2018.

[23] G. E. Mills and L. R. Gay, Educational research: Competencies for analysis and applications. ERIC, 2019.

[24] S. R. Wardani, A. Fuady, and A. Andayani,
"Peningkatan Keaktifan Dan Kemampuan Menulis Teks Anekdot Dengan Menggunakan Model Pembelajaran Make a Match Pada Siswa Kelas X Smk," BASASTRA, vol. 4, no. 1, pp. 168-182, 2017.

[25] F. Gumelar and Y. Mulyati, "MEME: Dapatkah Meningkatkan Kemampuan Siswa dalam Menulis Teks Anekdot?," Fajar Gumelar. Hlm, pp. 105-117, 2018.

[26] A. Sudirman, "Current issues in English-Indonesian translation equivalences," Int. J. Sci. Res., vol. 5, no. 2, pp. 1687-1695, 2016 